\title{
The Audiocast Diaries: Reflections on radio and podcasting for delivery of educational soap operas
}

\author{
Wendy Elliott \\ Masters of Distance Education Program \\ Athabasca University - Canada's Open University
}

\section{Introduction}

March 24, 2005: While studying Gender Issues in Distance Education at Athabasca University, I read about the nomadic Fulbe women in Nigeria who learned by radio. I could understand their concerns with uninspired educational radio programs that did "not take into consideration the rhythm of ... [their] lives" (Usman, 2001, p. 98). There was one tiny reference to a drama series, but as a scriptwriter and a woman interested in the power of storytelling as education, I was intrigued. The idea of serial drama as education was planted in my mind.

September 15, 2005: Determined to take my remaining two electives of the Master of Distance Education (MDE) program as independent study courses, I began searching the Internet for ideas. Eventually I discovered the concept of entertainment-education which consists of "two equally important parts: the format (entertainment) and the message (education)" (Johns Hopkins, 1998, p. 7). One striking example of entertainment-education is an educational soap opera called "Urunana." After the 1994 genocide in Rwanda, over 70 percent of the remaining population was under 24 years of age. Because most of Rwanda's health staff had either been killed or had fled, there was no one left to provide "specific information on sexual and reproductive health . . . [so] vital to the health of the nation" (Booth, 2003, ๆ 1). The circumstances were shocking, but the solution - Urunana delivered via radio - was fascinating. I began collecting information on educational soap operas - serial dramas whose purpose is education or social transformation. They were mostly played in developing countries, and mostly played on the radio.

October 10, 2005: I was alerted by a Really Simple Syndication (RSS) feed from one of my favourite websites, I Love Radio, that Internet audio had overtaken radio as the music preference for young people (Maffin, 2005). "They will pick, swap, mix, rip, burn, podcast, mod, and mashup their media . . . to present them with a personalized view of the world” (\$ 2). Maffin referred readers to a study of youth in eleven countries conducted by Yahoo and OMD Worldwide. It found that "the Internet has surpassed radio as the preferred medium for music among youth in all [of those] countries” (Radio Currents, 2005, ๆ 6). Similar findings from a survey of 12 to 24 year old North Americans cited the tipping point to be September 2004, when more young people were listening to new media than to traditional radio. "The same survey indicate[d] that the 25 to 59 and 35 to 64 age brackets are head[ed] in the same direction" 
(Burrill, 2004, ๆ 7). Note to self: Maybe a podcast educational soap opera would appeal to the more technologically sophisticated youth here in North America.

November 18, 2005: The 2006, Inukshuk Fund was launched in mid-October and the deadline for Canadian institutions or not-for-profit organizations to submit a proposal for innovative multimedia delivery of education was December 22 (Inukshuk Fund, 2005). Thinking I might interest an organization in my podcasting-soap opera idea, along with an offer of writing the proposal, I began to approach various organizations.

April 6, 2006: I spent several frustrating months contacting organizations, but was unable to spark any interest. Note to self: This may be an appropriate subject for an independent study course.

May 15, 2006: My independent study proposal for two courses on Radio, Podcast, and Soap Opera as Distance Education was approved by the MDE program director. I now had a supervisor, learning objectives, and renewed enthusiasm for the topic.

May 28, 2006: Watching an online streaming video, entitled The End of Radio (Giddens \& Ghomeshi, 2006), gave me the structure for this paper. I decided to examine the state of radio and its audio rivals, especially podcasting, report on my attendance at the Podcasters Across Borders (2006) conference, and conclude with reflections on audio formats suitable for delivery of educational soap operas.

\section{Radio}

June 1, 2006: Radio is a 20th century phenomenon. Its origins can be traced back to the first transatlantic wireless signal by Marconi in 1901 from Cornwall, England to St. John's, Newfoundland. In the early years, radio was a two-way medium freely used by amateurs, much like ham radio is today. During World War I, however, governments in North America and Europe decreed that only the military could operate radio stations (Ellerman \& Mackintosh, 2003; Sposato \& Smith, 2005). After the war, the main purpose of radio changed from military communications to entertainment. Commercial radio stations began to appear, the first one in North America being XWA (later CFCF) in Montreal in 1919 (Ellerman \& Mackintosh, 2003), although the Americans claim KDKA in Pittsburgh in 1920 as the first (Sposato \& Smith, 2005). In any case, there was "an explosion in the demand for radio. In the United States, 100,000 sets were sold in 1922, and a half million the next year" (Ellerman \& Mackintosh, 2003, Public Broadcasting, ๆ 1).

Governments began to regulate the radio industry heavily, turning it into a one-way medium, controlling content, and limiting frequencies and ownership (Ellerman \& Mackintosh, 2003; Sposato \& Smith, 2005; Thomas, 2001). Even so, people clamoured for the sound of the human voice.

Radio announcers were unusually young, and spoke with enthusiasm and spontaneity. Radio news was taken directly from the news wire and read without interpretation. This gave the broadcasts an appearance of honesty and immediacy that spoke eloquently to the poor, to women, and to people in rural areas (Ellerman \& Mackintosh, 2003, Public Broadcasting, ๆ 4). 
June 3, 2006: I was thrilled to discover the possibility that the first few educational serial dramas (or soap operas) were produced here in Canada. Buck (2006) documented the 1927 production of the Canadian National Railway's Radio Train, a program for children about a group of adventurers who traveled across the country on an imaginary train. In each episode, listeners would learn about the history and geography of a stop en route. In May 1939 the Canadian Broadcasting Corporation (CBC) broadcast the first of over 6,000 eight-minute episodes about The Craigs, an Ontario farm family. It was soon followed by other "families" in other regions in Canada dealing with farming practices (McNeil \& Wolfe, 1982).

Following World War II, "educational radio spread from the industrialised nations of Europe and North America to the developing countries . . . especially in the areas of agriculture and health" (Thomas, 2001). One reason for this was probably due to the work of Mexican writer producer director Miguel Sabido who, in the 1970s, "developed a methodology for entertainment education soap operas” (Singhal \& Rogers, 1999, p. 14). Several things also happened in the 1970s that contributed to the rise of entertainment-education radio soap operas: frequency modulated (FM) radio transmission was developed, miniaturization of radio transmitting stations became more common, and portable AM/ FM radio receivers became more available at a relatively low cost (Thomas, 2001).

Despite the popularity of television in Western nations, entertainment-education soap operas continue to be delivered via radio in developing countries because radio is still the dominant medium there. For example, in Rwanda there are still 101 radios for every television set (Booth, 2003), and gathering around the radio to listen is still a common group or community activity.

June 5, 2006: The digital revolution took its time getting to radio. Now it is exploding - and the big bang goes far beyond podcasting. As radio shows are turned into digital bits, they are being delivered many different ways, from Web to satellite to cell phones. Listeners no longer have to tune in at a certain time, and within range of a signal, to catch a show or a game. As the business goes digital, the barriers to entry - including precious airwaves - count for less and less (Green, Lowry \& Yang, 2005, Easier Entry, ๆ 2).

The explosion in audio media includes satellite radio, high definition, online radio, Wi-Fi, podcasting, and cell phones. Note to self: Almost all sources regarding new technology are from North America or Europe, and most references are to commercial radio. Keep this in mind when considering entertainment-education soap opera delivery.

June 6, 2006: Commercial radio is a US $\$ 21$ billion industry in the United States. Satellite radio is a subscription-based medium, and the few satellite-radio companies that exist are taking aggressive steps for a piece of that pie. Sirius hired shock jock Howard Stern at US \$500 million over five years, and $X M$ hired Bob Dylan and other famous personalities, to draw in paying customers (Green et al., 2005). There are 10 million satellite-radio subscribers worldwide, and both Sirius and $X M$ expect to have 15 million subscribers in North America alone by the end of 2006 (Giddens \& Ghomeshi, 2006). Even so, both companies are not "expected to turn a profit until at least 2008... [and] are at the beginning of their growth curve" (Green et al., 2005, Sky High Ambitions, ๆ 3).

June 7, 2006: High Definition (HD) radio, also known as Digital Audio Broadcast (DAB), has been around for a few years, but has not caught on because normal AM/ FM radio - now known as terrestrial radio - stations could not agree on standards (Giddens \& Ghomeshi, 2006). HD radio produces $C D$ quality sound. By the end of the decade, at least 2,500 stations in North 
America are expected to have it. Radio executives are betting that HD will allow them to offer the kind of niche programming already available on satellite radio and on the Web. In the next few years, HD will feature TiVo like functions, enabling listeners to store music and news and get on demand content (Green et al., 2005, On Demand, ๆ 1).

June 8, 2006: Online radio seems to have the same problem that websites have - how to pay for it. Audiences of Internet radio players, such as AOL, Yahoo and MSN, have plateaued at around 19 million listeners, perhaps because "some companies limited the music people could hear online to avoid paying heavy royalties” (Green et al., 2005, On New and Improved, ๆ 1). Seeking advertisers is one way around the problem, but as one blogger wrote, this may not work. Referring to the Internet-versus-radio survey (see my diary entry for October 10), he noted that it found that the more personalized the media stream, the less receptive consumers are to accompanying advertising. "This seems intuitive: the more the product is supposed to be about meeting your desires, the more off putting it's going to be to be suddenly subjected to a message that's all about somebody else's” (Fine Young Journalist, 2005, Where Do We Go, ๆ 2).

Perhaps audience participation is the answer. Infinity Broadcasting, one of the largest American radio operators with 813 stations, played listeners' uploaded homemade digital audio files. "Infinity's [spokesperson] . . . said the decision to launch the 'open source radio' experiment came partly because the San Francisco station's current format has not been a great financial success” (Jardin, 2005, ๆ 11). As an indication that some see huge financial potential in online radio, however, Fox News paid US \$580 million in 2005 for myspace.com, a music-driven website with over 70 million members and 1.5 billion page views per-day (Giddens \& Ghomeshi, 2006).

June 8, 2006: So, is terrestrial radio dying? Probably not soon. Despite the rise of new technology, notably the Internet, in the 1990s and 2000s, there is still a large disparity in the distribution and use of media. Compare the use of the Internet versus radio around the world: 33.1 percent versus 81.3 percent in Europe; 1.5 percent vs. 19.8 percent in South Asia and sub-Saharan Africa; 0.4 percent vs. 27.7 percent in the Middle East and North Africa; and 9.2 percent vs. 41 percent in Latin America and the Caribbean (United Nations World Youth Report, 2005). Even in North America, with Internet accessibility at a very high rate - 78 percent in Canada (Canadian Radio television, 2006) - "no one is saying commercial radio is going away: It still draws more than 200 million listeners a week” (Green et al., 2005, Ads and Minuses, ๆ 3). Or, as one radio supporter said: "If I created a technology today that reached 95 percent of the population [in North America], was free, was portable, and was ubiquitous, what would you say about it? It's, like, well, it was created - it’s radio” (Giddens \& Ghomeshi, 2006, 1:11 - 1:25).

\section{Podcasting}

June 16, 2006: Podcasting is a new word for delivering compressed audio files (usually MP3) over the Internet. It is a combination of iPod (Apple's popular audio player) and broadcasting (Colombo \& Franklin, 2005; Crofts, Dilley, Fox, Retsema \& Williams, 2005; Jardin, 2005). It is a controversial word among podcasters because it implies that a person needs an iPod to listen to a podcast, which is not true (Campbell, 2005; Meng, 2005). Podcasts can be played on any computer, and downloaded to almost any portable music player.

It has been possible to download audio files for many years, almost since the World Wide Web was created. What is new is "the ease of publication, ease of subscription, and ease of use across multiple environments” (Campbell, 2005, p. 2). Podcasting became possible in 2004 when 
software engineer Dave Winer adapted RSS software to handle audio files (Crofts et al., 2005), and Adam Curry developed podcasting software when he "saw the potential of technology to help provide greater flexibility in finding and downloading audio files . . . automatically . . onto his iPod" (Crofts et al., 2005, Introduction, I 5).

Podcasting enables independent producers to create self-published, syndicated "radio shows," and gives broadcast radio programs a new distribution method. Podcasting is not just about the digital audio, it is the process by which knowledge in an audio format around a certain theme or topic can be discovered, subscribed to, and downloaded. It is a process that helps the listener find interesting content that is relevant to them through classifications ( . . tagging) and it allows the listener to play the audio at a time that is convenient to them, simply and easily. This enables an occasionally connected person, particularly in the development and education context, to have a list of relevant content readily available at her/ his fingertips (Roberts \& Sarkar, 2005, p. 3).

June 18, 2006: "Podcasts consist of any imaginable form of audio content, from spoken word programs by bloggers to shows made by professional radio organizations” (Jardin, 2005, I 14). They are rapidly increasing in popularity because they are simple to produce and very inexpensive to deliver. "At it's [ sic] simplest, all that is required to create a podcast is a personal computer with a sound card, an inexpensive or built-in microphone, sound editing freeware, and an Internet connection with access to a website. Because of the low cost of entry, anyone can be a publisher, or more accurately a broadcaster with their own radio show” (Meng, 2005, p. 3).

June 22, 2006: I downloaded my favourite CBC radio shows, educational audio-blogs, comedy podcasts, and music, then uploaded them to my MP3 player and headed down the road to Kingston, Ontario to attend the first Podcasters Across Borders (2006) conference. The four-hour drive, including bumper-to-bumper traffic through Metro Toronto, was made bearable by listening to the player with one "ear bud" rather than a headset (which, I think, is illegal while driving). Note to self: Look into the cost of a car radio that connects with a portable music player.

June 23, 2006: A friend in Kingston took me to a discount store to purchase a cassette with a cable that attaches to an MP3 player, enabling me to listen to podcasts headset-free from my car's cassette player! Note to self: A cassette device is cheaper than a new car radio; think creatively when thinking about alternatives!

Shelagh Rogers, host of CBC Radio's Sounds Like Canada, gave the keynote address to open the Podcasters Across Borders (2006) conference. She affirmed that podcasting had revolutionized independent radio, giving the individual a voice and an audience that was never before possible. She spoke about the power and intimacy of radio, and reminded those present to talk to one person - not to the masses - and to tell compelling stories.

June 24, 2006: There were seven presentations during the conference, covering such things as planning a podcast, interviewing techniques, building a studio, and niche programming. The latter was particularly pertinent because of the diverse nature of podcasting. The participants consisted of about 80 enthusiastic people, most of whom were podcasters whose shows were targeted to comic book devotees, paramedics, motorcycle enthusiasts, hip hop dancers, techno-geeks, and Marilyn Munroe fans, among others.

Because I have produced several digital videos, and have written many scripts for video and radio, I was familiar with most of the information covered in the presentations and discussions. I did pick up a few podcasting tips, however, and noted a few interesting things. 
Although podcasting is a method of delivery, at least half of the conference attendees also consider it a culture. They are passionate about keeping its independent spirit, and are worried about the change or influence big business's participation might bring. They strive to produce podcasts that are more professional than amateurish, but not without the spontaneity that flubs or mistakes bring. Although Giddens and Ghomeshi (2006) estimate that there are currently about 10,000 podcasts on the Internet, the number 50,000 was bandied about at the conference. For every new podcast, however, it was assumed that at least one had ceased, due to the amount of work required to produce them regularly.

Some podcasters had a narrow definition of this culture, which did not include educational podcasts, which they equated with university lectures. The few people who saw podcasting as an alternative delivery for any content produce podcasts that had some educational elements, such as the man who founded a project for recording copyright-expired books, or the public relations expert who ran a podcast for his industry, or the lawyer who created a podcast on legal issues, or the emergency medical services guy who has an avid international audience.

Perhaps the most interesting thing is that although podcasting is much like radio, in that it is a one-way medium, most podcasters consider it as two-way communication because their podcasts are available on websites and they have either accompanying blogs to which listeners add comments, or provide email addresses for listeners to write to them. The podcasters consider it a point of pride that they respond to their listeners' comments, both in their blogs and in subsequent podcasts, thus creating an asynchronous dialogue.

June 24, 2006: On the way home, I listened to the podcasts of several people I had met, and reflected on the comments I'd heard during the conference that echoed things I'd read in the past few months:

- "The key technological advantage of podcasting is time-shifting - the ability to listen to audio material when we choose” (Crofts et al., 2005, Social Contributions, ף 2).

- "The Internet has surpassed radio as the preferred medium for music among youth" (Radio Currents, 2005, I 6) and "younger people have become accustomed to personalizing their experiences with interactive media” (\$ 1).

- “As old fashioned radio struggles, listeners are creating the future” (Green et al., 2005, Buying a Song, I 3). "With no licenses, no frequencies, and no towers, ordinary people are busy creating audio programming for thousands of others. They're bypassing an entire industry” (Green et al., 2005, Easier Entry, \ 1).

- "The strength of podcasting is in its technical simplicity ... More exciting is the interest it has spawned in the creation of grassroots audio content from around the world" (Roberts \& Sarkar, 2005, p. 4).

- "Around six million ... people have downloaded podcasts, and podcasting is expected to reach 12.3 million households [in the United States] by 2010" (Crofts et al., 2005, Intro., \10).

- How will podcasts be funded? "While start-ups such as Odeo and The Podcast Network are providing technological support and creating a podcasting network, right now Ibbott has barely enough ads to cover expenses, and most podcasters work for free” (Green et al., 2005, ๆ 2). 
- And as for educational soap operas? "Podcasting could have far reaching opportunities for international development in the creation of freely available educational and development content” (Roberts \& Sarkar, 2005, p. 4).

\section{Cell Phones}

June 26, 2006: Not owning a cell phone, I did not considered it a device to deliver audio soap operas. I was wrong. It is already happening, albeit in a rudimentary fashion. User-subscribed, they are called "mobisodes," presumably for mobile soap episodes: "Some are cartoon strip images with captions, others use familiar soap locations and storylines with well known actors. At present the mobisodes are static images with text, rather than video scenes” (Millea, Green \& Putland, 2005, p. 72).

A soap opera called Jong Zuid is already very popular on cell phones in the Netherlands and even won an award for best mobile application (Mobile Tech News, 2003). But full audio/ video "mobisodes" are no doubt coming soon. They will probably be delivered via wireless Multimedia Message Service (MMS) which can transmit video clips, sound files, text messages, and email. "Use in an educational context is still in the early days in that MMS-ready mobile phones are not yet ubiquitous, although take-up is increasing” (Millea et al., 2005, p. 72). Cell phones are already the preferred camera for many people (BBC News, 2006, June 6), in use as visual radio delivering FM music with artists' photos (Jardin, 2005), and used as music or podcast players (Needleman, 2006). Although MP3 players, Personal Digital Assistants and other mobile devices flood the marketplace, with 815 million people buying cell phones last year (Giddens \& Ghomeshi, 2006), and an estimated 2.5 billion mobile phones in use around the world (BBC News, 2006, June 6), is it any wonder Needleman (2006) said: "It's a bit early to say definitively which model will win out, but it's worth noting that for most people, a cell phone is a necessity . . . I think that indicates which way the market is going to tilt” (ף 6).

\section{Costs and Other Considerations}

June 27, 2006: Millea et al. (2005) found "considerable agreement in the literature on the general trends in emerging technology" (p. 10). They include mobility, interoperability between devices, convergence of functionality but divergence of use, integration and customization, the richness and malleability of content, security issues, open source, and opportunities for creativity, interactivity and collaboration.

All these things come at a price, however. For example, listening to satellite radio requires between US \$100-\$400 for the hardware and about US \$15 per month for the subscription fee (Giddens \& Ghomeshi, 2006). Listening to podcasts requires a highspeed Internet connection, because most podcasts are a minimum of $9 \mathrm{MB}$ and many run to $35 \mathrm{MB}$ or more. The average monthly cost of highspeed connection is US \$30-50/month, and MP3 players cost between US $\$ 100-500$. It is even more expensive to create the podcasts. Even though they can be created with minimal software and hardware, the average podcaster's studio costs between US $\$ 1,000-5,000$ (Podcasters Across Borders, 2006). Moreover, the costs for downloading can increase relatively with the popularity of the podcast and amount of bandwidth used. "Most [Web] hosting plans define an allowable amount of bandwidth each month for a particular price" (Colombo \& Franklin, 2006, p. 120) and charge extra for any bandwidth used above that. This cost is especially important for online radio: 
You pay for every single listener who tunes in or streams your radio station. The broadcast model is absolutely opposite. You pay one time to put that stuff out in a giant pipe, and you can have ten people listening or ten million, and it'll cost you the same amount (Giddens \& Ghomeshi, 2006, 19:50 - 20:04).

So, terrestrial radio still seems to be cheaper - for the listener, at least. Producing radio is still a business (and therefore too costly for the average person to set up a station), and is still controlled by commercial enterprises, public radio, and community or campus radio. That is changing, too. Referred to as a radio station in a suitcase, there is a compact package designed and manufactured in Manitoba and distributed in developing nations by the Commonwealth of Learning. It has all the hardware needed to create portable radio transmission, including the ability to connect to commercial FM networks and satellite feeds. "It broadcasts up to a 50-km radius, runs on a car battery, and can be modified for solar power . . . all for around US \$3,500 (Chin, 2000, p. 1).

But what of the listeners? While most in the Western world have access to radio (see diary entry June 8), listeners in the developing world are not so fortunate. "Nearly seven out of ten Bolivian households have radios, a proportion far greater than any of the other eighty poorest countries in the world" (Education Development Center, 1998). Organizations such as the Freeplay Foundation are trying to change this by selling inexpensive (subsidized) radios to those in need. Their Lifeline Radio is a self powered (wind-up or solar power) created "specifically for children living on their own, distance education or other humanitarian projects” (Freeplay, 2006, ๆ 3).

It would seem that radio might be the most appropriate delivery for educational audio in developing regions, except for this surprising fact: Some developing nations are going wireless. Mbarika and Mbarika (2006) note that "sub Saharan Africa - with 34 of the 50 poorest countries on Earth, according to the United Nations - is now the world's fastest growing wireless market" ( (13), mainly because the "national telecommunications monopolies are poorly managed and corrupt, and they can’t afford to lay new [land] lines or maintain old ones” (\$ 4). Cox (2005) points out that most poor communities are off the electrical grid with only one in ten people having access to electricity. It makes economical and practical sense for people to use cell phones for communication, which run on either small batteries, car batteries with adapters, or solar power.

New mobile devices just might be the answer - with capabilities of a telephone, radio, text messenger, podcast, and computer combined. Already the new Zing device has the ability to connect to satellite radio and the Internet through its wireless technology, record through its microphone, play with its built-in speakers, and talk to others "walkie talkie style, over the Wi Fi network” (Needleman, 2006, ๆ 5), and some mobile phones have MMS capabilities (Millea et al., 2005).

\section{Conclusions}

July 1, 2006: Yesterday results of an Ipsos poll revealed that 20 percent of Americans over the age of 12 now own an MP3 player, a rise from 10 percent only three years ago (BBC News, 2006, June 30). While both radio and podcasting are appropriate current choices for delivery of educational soap operas, it is difficult to know which medium (if either) will dominate the 21st century. Recalling AM radio, Buck (2006) commented that "some of the ideas it embodied and other ideas that were tried and found wanting may be worthwhile to consider in light of 'new' approaches such as podcasts and netcasts" (p. 87). However, "predicting the likely adoption and 
evolution of emerging technology is, of course, a best guess scenario, given the rapid state of change in the digital world” (Millea et al., 2005, p. 20).

In this challenge, however, is also the opportunity to provide all new classes of services for on campus, distance, and lifelong learners. In fact, the greatest opportunities for these technologies are in the ways they will be used that have not been imagined yet (Meng, 2005, p. 11).

My bet is on some sort of convergence of radio, podcasting, and mobile phones which will provide learners with the convenience of listening to episodes wherever, whenever they want, provided that connections and downloading costs are not too prohibitive. Maybe this new technology, which allows two-way communications, will change radio back to its origins of a two-way medium, as it was in Marconi's day. Maybe people will listen to the soap operas and discuss what they have learned with others, thereby supporting the trend in education toward collaborative learning. At the rate that technology is advancing, I do not think we will have to wait too long to see.

\section{References}

BBC News. (2006, June 6). Handsets look to eclipse cameras. Retrieved June 6, 2006 from: http://news.bbc.co.uk/2/hi/technology/5048966.stm

BBC News. (2006, June 30). Digital music fans reach new peak. Retrieved June 30, 2006 from: http://news.bbc.co.uk/2/hi/technology/5132398.stm

Booth, I. (2003). Radio Soap for Health Education: Lessons learnt by Health Unlimited Rwanda 1997 2003. Retrieved September 15, 2005 from: http://www.comminit.com/evaluations/ steval/sld 2172.html

Buck, G. H. (2006). The First Wave: The beginnings of Canadian distance education. Journal of Distance Education, 21(1), 75 - 88.

Burrill, W. (2004). Teens fleeing adult radio. Retrieved November 1, 2005 from: http://friends.ca/News/Friends_News/archives/articles12060401.asp

Campbell, G. (2005, November/ December). There’s something in the air: Podcasting in education. EDUCAUSE Review. Retrieved October 21, 2005 from: http://www.educause.edu/ir/library/pdf/erm0561.pdf

Chin, G. (2000). The Suitcase Station: Have radio, will travel. The Commonwealth of Learning website. Retrieved June 4, 2006 from:

http://www.col.org/programmes/clippings/pdfs/suitcase.pdf

Colombo, G., \& Franklin, C. (2005). Absolute beginner's guide to podcasting. Indianapolis, IN.: Que Publishing.

Cox, F. (2005). Coming Together: Energy from the sun. The Commonwealth of Learning website. Retrieved June 20, 2006 from: http://www.col.org/media/EnergyfromtheSun.doc 
Crofts, S., Dilley, J., Fox, M., Retsema, A., \& Williams, B. (2005). Podcasting: A new technology in search of viable business models. First Monday, 10(9). Retrieved September 19, 2005 from: http://www.firstmonday.org/issues/issue10_9/crofts

Education Development Center Inc. (1998). Multichannel Learning Center: Ten years of sustained involvement in Bolivia. Retrieved November 21, 2005 from: http://main.edc.org/newsroom/features/mcl.asp

Ellerman, E., \& Mackintosh, J. (2003). Radio: The People’s Medium. Athabasca University’s Communications Studies' website. Retrieved November 1, 2005 from : http://www.athabascau.ca/courses/cmns/302/unit6guide.html

Fine Young Journalist (2005). Slicing and Dicing. Retrieved October 15, 2005 from: http://fineyoungjournalist.blogspot.com/2005/10/slicing and dicing.html

Freeplay Foundation (2006). What is Lifeline Radio? Freeplay Foundation website. Retrieved April 29, 2006 from: http://www.freeplayfoundation.org

Giddens, D., \& Ghomeshi, J. (2006, May 6). The End of Radio. Online video of original television broadcast. CBC Newsworld online. Retrieved May 28, 2006 from: http://www.cbc.ca/theend/radio.html

Green, H., Lowry, T., \& Yang, C. (2005, March 3). The New Radio Revolution. Business Week Online. Retrieved June 4, 2006 from: http://www.businessweek.com/technology/content/mar2005/tc2005033_0336_tc024.htm

Inukshuk Fund (2005). Inukshuk Wireless website. Retrieved November 18, 2005 from: http://www.inukshuk.ca/anglais/nous.html

Jardin, X. (2005, April 27). Podcasting killed the radio star. Wire News. Retrieved November 1, 2005 from: http://www.wired.com/news/digiwood/0,1412,67344,00.html

John Hopkins University (1998). Johns Hopkins University Center for Communication Programs: A report on the second international conference on entertainment-education and social change. Baltimore: JHU/ CCP. Retrieved April 13, 2006 from: http://www.jhuccp.org/pubs/sp/9/9.pdf

Maffin, T. (2005). Why radio needs to become interactive immediately. Retrieved October 10, 2005 from: http://todmaffin.com/blogs/radio/category/other/trends/page/2

Mbarika, V. W. A., \& Mbarika, I. (2006). Africa Calling. Retrieved June 29, 2006 from: http://www.spectrum.ieee.org/may06/3426

McNeil, B., \& Wolfe, M. (1982). The Birth of Radio in Canada: Signing on. Toronto: Doubleday.

Meng, P. (2005). Podcasting and Vodcasting: A white paper. Retrieved September 19, 2005 from: http://edmarketing.apple.com/adcinstitute/wpcontent/Missouri Podcasting White Paper.pdf 
Millea, J., Green, I., \& Putland, G. (2005). Emerging Technologies: A framework for thinking. Australian Capital Territory Department of Education and Training. Retrieved October 1, 2005 from: http://www.det.act.gov.au/publicat/pdf/emergingtechnologies.pdf

Mobile Tech News (2003). Ericsson's Best Mobile Application Award 2003. Retrieved November 8, 2006 from: http://www.mobiletechnews.com/info/2003/11/30/002548.html

Needleman, R. (2006). Coming Soon: The Wi Fi MP3 player. Retrieved June 4, 2006 from:

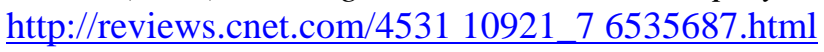

Podcasters Across Borders (2006). Podcasters Across Borders Conference in Kingston, Canada. June 23-24, 2006. Retrieved November 8, 2006 from:

http://www.podcastersacrossborders.com

Radio Currents Online (2005, September 27). Yahoo OMD Study: Youth prefer the Internet over radio. Retrieved October 15, 2005 from:

http://beradio.com/currents/radio_currents_092605/

Roberts, M., \& Sarkar, P. P. (2005). Podcasting: Knowledge sharing for development through dialogue. Retrieved May 30, 2006 from: http://conversations. bellanet.org/Podcasting_concept note.pdf

Singhal, A., \& Rogers, E. M. (1999). Entertainment Education: A communication strategy for social change. Mahwah, NJ.: Lawrence Erlbaum Associates. Retrieved May 21, 2006 from: www.colby.edu/education/courses/ed116/Enter_Educa.doc

Sposato, S., \& Smith, W. A. (2005). Radio: A post nine-eleven strategy for reaching the world's poor. Lanham, MD.: University Press of America.

Thomas, J. (2001). Using community radio for non formal education. The Commonwealth of Learning website. Retrieved February 16, 2006 from: http://www.col.org/Knowledge/ ks_radio.htm

United Nations World Youth Report (2005). Information and communication technologies. Retrieved June 20, 2006 from http://www.un.org/esa/socdev/unyin/wpayinformation.htm

Usman, L. (2001). "No One Will Listen to Us” Rural Fulbe women learning by radio in Nigeria. In E. J. Burge \& M. Haughey (Eds.) Using Learning Technologies: International perspectives on practice (pp. 92-101). London: Routledge-Falmer. 